\title{
PARA SER FELIZ: MEMÓRIAS DE MINHA ALFABETIZAÇÃO*
}

\author{
Joselita Maria da Silva e Silva (SEMED/ROO)
}

Nasci em 1963, na cidade de São Paulo, filha de pais que mal sabiam ler e escrever, mas que davam enorme valor aos estudos e se esforçavam ao máximo para não faltar o básico, tanto em casa como na escola, justamente porque lhes foram negadas as mesmas oportunidades que nos proporcionavam.

Minha alfabetização começou, pelo que me lembro, em casa mesmo, pois meu irmão, um ano mais velho que eu, já estudava e comentava comigo o que havia aprendido. Ainda posso visualizar a cena de quando ele me ensinou a marcação do parágrafo, medindo com seus dedinhos na folha em branco. Eu ficava encantada! Ele me ensinava algumas letras também e, quando ingressei na escola, já conhecia algumas coisas. Imaginem só: eu nem sabia ler e escrever, mas já sabia a marcação do parágrafo! Recordome, também, do modo como ele me ensinou a grafia da letra "a": - Você tem que escrever a letra "a" meio deitada!

Em 1970, minha mãe me matriculou na mesma escola municipal que meu irmão estudava, num bairro periférico de São Paulo, Capital. Essa escola existe até hoje. Era um bocado longe de casa, todavia, a mais próxima. Assim, depois do almoço, lá íamos nós para a aula, com as bolsas de tecido que minha mãe costurava para levarmos os materiais. Entrávamos às 13 horas e saíamos às 17 horas.

O pai de um casal de amigos e vizinhos nossos passava na escola, na saída do seu trabalho e nos trazia para casa, mas antes passava numa merceariazinha do caminho para tomar um aperitivo depois da jornada e comprava doces para nós. Minha mãe brigava conosco por aceitar os doces, pois a situação financeira destes amigos, era mais difícil que a nossa. Mas, como resistir aos deliciosos suspiros, gibis (doces de amendoim) e picolés (que eram doces de banana em forma de triângulo e açucarados, presos em palitos)?

Minha irmã mais velha encapava os cadernos e livros para nós. Tudo comprado com muito sacrifício, pois éramos em cinco filhos de um pai metalúrgico e uma mãe que fazia malabarismos com o ordenado dele para não passarmos necessidades. Sou a filha do meio. Há dois mais velhos e

*DOI - 10.29388/978-65-86678-68-0-0-f.231-236 
dois mais novos que eu. Naquela época, os governos não forneciam materiais didáticos para os alunos. Por sorte, os livros não eram tão consumíveis como hoje, assim, podíamos conseguir com parentes ou pessoas conhecidas, utilizá-los e passá-los para o irmão que começaria naquela série no ano seguinte.

Não havia auxílio do governo para material didático, entretanto, existia uma ajuda para alunos muito carentes. Esses alunos recebiam uniformes, blusas de frio e, às vezes, uma alimentação diferente da dos demais. Eram denominados alunos da Caixa Escolar. Nossos uniformes eram compostos por camisa branca, cujo bolso tinha o emblema da escola e do município, calça azul-marinho ou saia pregueada, meias 3/4 brancas e sapatos pretos. Não era permitida a entrada dos alunos se faltasse qualquer um destes itens, a não ser com um bilhete escrito pela mãe ou responsável explicando o motivo de estar com o uniforme incompleto.

Por exigência da escola, os materiais eram encapados com papel manilha, um papel mais resistente, o que não impedia que os meus ficassem com orelhas de vez em quando. Eu detestava aquilo e tentava prensálos para melhorar a aparência. Tínhamos atividades de cobrir letras, para treino da coordenação motora e essas letras, depois, eram "desenhadas" no caderno. Hoje, as crianças são alfabetizadas, primeiramente com letra bastão, para depois aprenderem a cursiva. Naquela época, o caminho era inverso: a alfabetização se dava pela letra cursiva e, posteriormente, apren díamos a bastão maiúscula e minúscula. O livro didático que norteava a alfabetização na minha primeira série era a cartilha Caminho Suave, de Branca Alves de Lima.

Eu adorava a cartilha! Os desenhos me fascinavam! Como davam certinho (eu pensava) a letra " $b$ " na barriga do bebê, a letra " $c$ " no rabo do cachorro e "j" na jarra! E depois, as sílabas complexas com o "nh" de "Nhá Maria e seu feixe de lenha". Eu tinha um universo inteiro a descobrir, desvendando cada letra e cada palavra! Eu tinha "fome" de aprender a ler!

Meu ponto fraco era a Matemática. Não era minha disciplina favorita. Posso dizer que aprendi bem, embora não me lembre do uso de materiais concretos para essa aprendizagem. Eu utilizava um recurso, que vejo os alunos usando até hoje, que era o desenhar bolinhas para somar, subtrair ou dividir. Todavia, as aulas de Língua Pátria, como eram chamadas na época, me fascinavam! Como era bom descobrir uma palavra nova, seu emprego e significado! Recordo-me de uma atividade, na qual a professora perguntava o que significava "extensão". Eu já havia ouvido a palavra, porém não conseguia descrever seu significado. Busquei na mente e me lembrei de 
alguém instalando uma antena de televisão e dizendo que o fio da referida antena, tinha tantos metros de extensão. Pronto! Havia achado a resposta! Então respondi: "Extensão significa metros!". Acredito que ainda não havia encontrado as palavras corretas para explicar, mas a professora considerou minha resposta. Que alegria! Só eu consegui acertar a resposta!

Eu era apaixonada pelas aulas de Português. Minha professora colocava uma gravura na lousa e, observando-a, tínhamos que fazer uma "composição", como eram chamadas as redações e as atuais produções de textos. Eu as escrevia e depois fazia as ilustrações. E, quando a professora escolhia uma para exemplificar para os demais alunos, era uma glória para o escolhido. Acho que tentávamos fazer o melhor texto possível para que a professora lesse para os colegas. Acredito que isso funcione até os dias de hoje como incentivo para a escrita.

Adorava ouvir as histórias contadas pela professora e, quando aprendi a ler, pegava revistas e gibis escondidos da minha irmã, que era muito brava, e "devorava-os"! Li escondido dela, um livro chamado "Mil e uma noites", que contava histórias de Simbá, o marujo, Aladim, Ali Babá e os quarenta ladrões e Sherazade, dentre outros personagens. Eram dela, também, as revistas Sétimo Céu, Capricho e outras que tinham fotonovelas. Eu queria ler, não me importava muito com o suporte. Depois que aprendi a ler, lia todos os livros que passavam nas minhas mãos. Sempre pedia para a professora, quando terminava minhas tarefas, para me entregar o livro de Português para eu ler as histórias nele contidas.

O método utilizado pelas escolas da época era o silabado. Aprendíamos as letras, depois as famílias silábicas e, posteriormente, a junção das sílabas em palavras e estas em frases. Não me recordo de ter havido alguma dificuldade para aprender. Talvez na grafia das letras $q, f$ e g. Até mesmo alguma confusão inicial com a danada da barriga dessas letras, ora para frente, ora para trás. Então, me lembro perfeitamente de uma frase na lousa que demorei um tempão, lendo e relendo até compreender para que lado estava a barriga da letra q e daí ler corretamente. A professora escreveu: Aquele é seu irmão, menino? Mas eu lia: Aguele é seu irmão, menino. Sem a interrogação. Eu pensava: mas será que um garoto está xingando o outro? Que xingamento é esse: aguele?! Jamais me esqueci e rio sozinha até hoje.

Recordo-me, também, de como a professora nos ensinava a letra "S", com a cantiga "Bambalalão, senhor capitão, espada na cinta e ginete na mão." E ia desenhando a letra na lousa. Na minha lembrança era a letra, mas, possivelmente, ela ensinava a desenhar as ondas do mar e, como ela 
falava "ginéte", eu cantava "espada na cinta e gilete na mão". (mas, o que o capitão faria com uma gilete na mão? - pensava eu.)

Gostava muito das outras disciplinas, mas não era uma aluna que me destacava entre os demais. Era extremamente tímida! Tinha muita vergonha de falar. Gostava mais de escrever. Nas aulas de Educação Física, que eu nem sabia que existiam, eu era uma negação. Conhecia as brincadeiras, mas a vergonha me impedia de aproveitá-las. As coleguinhas brincavam de roda, com cantigas que me lembro até hoje. Eu até que participava, mas quando havia aquelas que alguém tinha que ir para o meio da roda dançar ou recitar algum verso, eu passava a vez para outra amiguinha. Algumas cantigas são usadas até hoje como "O cravo brigou com a rosa", como textos para interpretação ou outra finalidade, pois, infelizmente, as meninas já não brincam mais de roda. E se a atividade era com todos os colegas juntos, como o jogo de queimada, por exemplo, eu preferia ficar de fora apenas observando.

A professora chegou a reclamar para minha mãe, todavia a timidez era maior do que eu! Mas, se a cantoria era na sala, com a professora nos ensinando uma música, eu adorava e participava, pois, em meio aos demais colegas, eu me sentia mais segura, afinal, ninguém me notaria. Uma das músicas que me marcaram ouço ainda hoje por aí. Não sei o motivo, mas associo a cantiga ao entardecer, provavelmente cantávamos para preencher o tempo vago ao final da aula. Tem esses versos: Para ser feliz/é preciso ver/esse céu azul da imensidão. / É fazer das tristezas estrelas a mais/ e do pranto uma canção [...].

Muitas qualidades do ensino de tempos anteriores permanecem ainda hoje como a formação do cidadão crítico e consciente de seus deveres e direitos, atuantes na sociedade que o circunda. O que mudou e, para melhor, são as formas de promoção do aluno. Antes, o estudante que apresentava dificuldades de aprendizagem, demorava para avançar. Ele permanecia na mesma série por dois ou mais anos. Atualmente, o discente com déficit no aprendizado tem mais chances de aprender. A escola pode ressignificar o ensino em favor desse aluno, oferecendo apoio pedagógico, materiais e atividades que venham a auxiliá-lo neste processo.

Enfim, são essas as minhas memórias mais marcantes do tempo da alfabetização. Como eu era feliz! E ainda sou! Apenas acrescento a essa felicidade uma pitada de preocupação quanto aos tempos que estamos viven do e aos perigos presente na pandemia que o mundo atravessa, mas acreditando sempre em dias melhores. Acreditando em nossas crianças, no seu potencial e na educação do Brasil! 


\section{Referências}

LIMA. Branca Alves de. Cartilha Caminho Suave: Alfabetização pela imagem. Disponível em: https://pedagogiaaopedaletra.com/cartilhas-caminhosuave. Acesso em: 29 out. 2020.

Música Bambalalão. Disponível em: https://www.youtube.com/watch? v=Xu21hKte_UE. Acesso em: 29 out. 2020.

Música Pequeno Mundo. Disponível em: https://www.letras.mus.br/moacyr-franco/pequeno-mundo-its-a-world/. Acesso em: 29 out. 2020. 